\title{
Vývoj nástroje pro posuzování vybraných komponent a charakteristik kvality výuky: aplikace $v$ oblasti cizího jazyka ${ }^{1}$
}

\author{
Pavel Zlatníček, Karolína Pešková \\ Masarykova univerzita, Pedagogická fakulta
}

\begin{abstract}
Abstrakt: Studie se zabývá možnostmi zkoumání vybraných komponent a charakteristik kvality výuky: (a) motivování, (b) podpůrné učební klima, (c) práce s časem, (d) orientace na cíle výuky, (e) učitelův projev. V návaznosti na to popisuje vývoj nástroje pro posuzování kvality výuky v oblasti cizího jazyka. Studie je rozvržena do dvou částí. První část má přehledový charakter - je zde představena konceptualizace pojmu kvalita a oborově obecné a oborově specifické komponenty a charakteristiky kvalitní výuky. $V$ druhé části studie jsou prezentovány: (a) finální verze posuzovacího nástroje kvality výuky cizího jazyka; (b) metodologická a jazyková úskalí, na která výzkumníci během vývoje prezentovaného nástroje narazili; (c) výsledky pilotáže posuzovacího nástroje.
\end{abstract}

Klíčová slova: kvalita výuky, kvalita výuky cizího jazyka, nástroj pro posuzování kvality výuky, komponenty a charakteristiky kvality výuky

\section{Developing an instrument for assessing components and characteristics of instructional quality: application in the area of foreign language}

Abstract: This study deals with the research in instructional quality with respect to the following components and characteristics: (a) motivation; (b) supportive classroom climate; (c) time management; (d) goal-orientation; (e) teacher's performance. The study is divided into two parts. The first part serves as a survey study - conceptualizations of quality as well as some components and characteristics of instructional quality are introduced. The second part presents (a) the final version of an assessment instrument of quality in language instruction; (b) methodological and language problems which the researchers encountered; (c) results of a pilot study.

Keywords: instructional quality, quality of foreign language instruction, instrument for assessment of teaching quality, components and characteristics of instructional quality

\section{1 Úvod}

Kvalita výuky ve smyslu vědeckého konstruktu, kolem něhož by bylo možno rozvinout empirický výzkum, není v České republice dosud hlouběji rozpracována. Chybí zejména systematický výzkum kvality napřič kurikulem školního vzdělávání, který by zohledňoval odlišnosti vyplývající ze specifické povahy učiva v různých vyučovacích předmětech. Z přehledu odborné literatury vyplývá, že výzkum různých aspektů

1 Tato studie byla zpracována v rámci řešení projektu GA ČR P407/ 11/0262 Kvalita kurikula a výuky $v$ oborech školního vzdělávání. 
58 kvality výuky je doménou především přírodovědných (matematika, fyzika) a méně již jazykových nebo společenskovědních a estetických předmětů (Zlatníček, Ducháčková, \& Janík, 2010b, s. 33).

Pro náš výzkum, který zpracovává v rámci své disertační práce první autor tohoto textu, to znamená jistá úskalí, nebot' se jedná o oblast, která není zdaleka tak dobře výzkumně pokryta ani v zahraničním, tím spíše $v$ českém prostředí. V zahraničí byla v rámci výzkumu kvality výuky cizího jazyka významným přínosem videostudie DESI (Klieme et al., 2008), která je v oblasti tohoto oborově specifického výzkumu prozatím ojedinělá. V českém prostředí není doposud výzkum kvality výuky cizích jazyků dostatečně pokryt.

Předkládaná studie navazuje na naše dřivější práce věnované vymezování a posuzování kvality výuky (se zaměřením na kvalitu výuky cizího jazyka), ${ }^{2}$ prezentuje vývoj posuzovacího nástroje a problémy s tím spojené. Popisovaný nástroj, který bude využit mj. při analýze videozáznamu 28 hodin výuky německého jazyka ${ }^{3}$ a může být $v$ budoucnu použiván při prípravě začínajících učitelů cizího jazyka, umožňuje posouzení kvality výuky cizího jazyka z hlediska následujících vybraných oborově obecných a specifických komponent a charakteristik kvality výuky: (a) motivování, (b) podpůrné klima učení, (c) práce s časem, (d) orientace na cíle výuky, (e) učitelův projev. Vytvořený nástroj se primárně orientuje na vyučování (tj. působení učitele - sem řadíme komponenty/charakteristiky práce s časem, orientace na cíle výuky a učitelův projev), současně ale zahrnuje některé prvky výukové interakce učitel-žák (sem řadíme komponenty/charakteristiky motivování, podpůrné učební klima).

\subsection{Kvalita - konceptualizace (vymezení pojmu)}

Samotný pojem kvalita nabývá v kontextu vzdělávání mnoha různých významů. Podle řady autorů (např. Chvál \& Starý, 2009, s. 64) se pojem kvalita vyskytuje v pedagogické oblasti ve dvou různých významech: (a) jako obecný výraz pro pozitivní i negativní označení míry (úrovně) nějakého stavu (např. kvalita výuky angličtiny ve škole $X Y$ je vysoká/nízká); (b) pro vyjádření stavu, který je optimální, žádoucí, ideální, tedy a priori pozitivní (např. výraz je potřeba klást dưraz na kvalitu výuky, který implicitně předpokládá, zamlčuje, že je myšlena vysoká kvalita výuky). výše uvedení autoři dodávají, že ve vzdělávání se pojem kvalita používá často ve druhém z uvedených významů. Také Helmke (2003, s. 40) vymezuje kvalitu ve vzdělávání ve dvou významech: (a) kvalita jako vlastnost či zvláštnost předmětu nebo fenoménu - pojem je používán ve smyslu kvalitativních charakteristik; jako jev popisující (nikoliv hodnotící); (b) kvalita jako excelence, resp. jakost (Güte) - pojem je

2 Navazuje na předchozí práce prvního autora (Zlatníček, 2011a; Zlatníček, 2011b; Zlatníček, 2011c; Zlatníček, 2011d; Zlatníček, 2010a; Zlatníček 2010b; Zlatníček 2010c) i na studie dalších řešitelů projektu GA ČR P407/11/0262 (Janík, 2012; Janík, Lokajíčková, \& Janko, 2012 - v tomto čísle Orbis scholae; Slavík \& Lukavský, 2012 - v tomto čísle Orbis scholae).

3 Videozáznamy hodin výuky německého jazyka byly pořízeny $v$ rámci IVŠV videostudie, která proběhla na jaře 2012 na náhodně vybraných školách v Jihomoravském kraji. 
používán normativně k objektivnímu hodnocení jakosti, hodnoty či obecné úrovně nějakého předmětu.

Někteří autoři (viz Janík, 2012, s. 246 s odkazem na Posche a Altrichtera, 1997, s. 130) chápou „kvalitu jako řadu kvalit“. Kvalita (v souhrnném pohledu) tedy zahrnuje určité oblasti kvality, které je nezbytné popsat, aby mohly být srovnávány. Často se $v$ literatuře setkáváme $s$ přístupem, kdy je koncept kvality nahlížen v systémovém pohledu, což jej umožňuje diferencovat do různých úrovní (Fend, 1998, s. 358): (a) kvalita v rovině vzdělávacího systému (doména vzdělávací politiky a její administrativy); (b) kvalita $v$ rovině školy (instituce, na jejímž fungování se podílí vedení školy, učitelé, žáci a jejich rodiče); (c) kvalita v rovině výuky (v níž probíhají procesy vyučování a učení). Uváděné roviny se zpravidla prostupují, tzn., že nejsou samož̌ejmě disjunktní a nezávislé (srov. Žák, 2006, s. 11). V textu se orientujeme na kvalitu v rovině výuky, protože se v našem výzkumu zabýváme posuzováním vybraných komponent a charakteristik kvality výuky v oblasti výuky cizího jazyka.

Ve snaze o uchopení významu pojmu kvalita výuky uvádíme $v$ této kapitole dvě definice, které tento pojem charakterizují nejvýstižněji. První definicí navazujeme na již citované autory Chvála a Starého (2009, s. 64), kteří charakterizovali kvalitu výuky s odkazem na Průchu (1996) jako „žádoucí (optimální) úroveň fungování a/nebo produkce výukového procesu, která může být předepsána určitými požadavky (např. vzdělávacími standardy), a mưže být tudíž objektivně měřena“. Druhá definice, ze které pro potřebu našeho výzkumu a vývoje vlastního posuzovacího nástroje vycházíme, je od Helmkeho (2003, s. 41), který nahlíží na kvalitu výuky z hlediska komponent a charakteristik, které jsou relevantní pro hodnocení kvality výuky. Popisem těchto komponent a charakteristik a jejich rozdělením na oborově obecné a oborově specifické se budeme zabývat dále.

\subsection{Oborově obecné a specifické komponenty a charakteristiky kvality výuky}

Principy fungování obecného modelu kvality ve vzdělávání objasňují Chvál a Starý (2009, s. 64-67). Jak autoři uvádějí, má-li být model kvality výuky využitelný také za účelem analýzy či evaluace kvality výuky, je třeba, aby byl propracován do roviny operacionalizace. $\mathrm{O}$ tom lze uvažovat při pohledu na obecný model kvality prezentovaný ve studii citovaných autorů. $\mathrm{V}$ obecném modelu lze podle nich rozlišit tři základní roviny: (a) oblasti kvality, (b) kritéria kvality, (c) indikátory kvality. Janík et al. (2013) konkretizují uvedený model tím, že do něj začleňují další rovinu - jedná se o rovinu komponent/charakteristik zakládajících kvalitu výuky (viz Janík, Lokajiččková, \& Janko, 2012 - v tomto čísle Orbis scholae). Jejich model má tuto strukturu: (a) oblasti kvality, (b) kritéria kvality, (c) komponenty a charakteristiky kvality, (d) indikátory kvality.

Při vytváření oborově specifického modelu kvality (např. modelu kvality výuky cizího jazyka) je zapotřebí propracovat všechny čtyři zmíněné roviny. Vzhledem ke skutečnosti, že výuka $v$ rámci jakéhokoliv oboru vykazuje současně jak 
60 komponenty a charakteristiky oborově obecné, tak komponenty a charakteristiky oborově specifické, domníváme se, že je třeba tuto skutečnost při modelování kvality výuky v oborech zohlednit. Proto je žádoucí rozlišit: ad (c) oborově obecné a oborově specifické komponenty a charakteristiky kvality výuky, ad (d) oborově obecné a oborově specifické indikátory kvality výuky (viz Janík et al., 2013). Při vytváření modelu je dále vhodné zavést pojmy komponenty a charakteristiky kvality, které vyjadřují, co má být ve výuce jaké, aby to hovořilo ve prospěch její kvality (viz Janík, Lokajíčková, \& Janko, 2012 - v tomto čísle Orbis scholae).

Soubor takových komponent a charakteristik můžeme získat několika způsoby. Např. na základě expertního šetření, v jehož rámci získáme souhrn expertních názorů na to, jak by kvalitní výuka měla vypadat. Podobně to udělal v českém prostředí Žák (2006). Problém však tkví v tom, že není empiricky doloženo, zda to, co by experti považovali za důležité, by skutečně vystihovalo kvalitu výuky. Další možností je vyjít z rešerše již existujících modelů kvality výuky a kvality výuky cizího jazyka. Pro účely našeho výzkumu jsme zvolili druhou možnost.

Oborově obecné komponenty a charakteristiky kvalitní výuky (tabulka 1) jsou koncipovány v modelech kvality výuky (Helmke, 2009; Meyer, 2004; Brophy, 2010) jako „obor přesahující“. Jako problematická se u zmíněných „obor přesahujících“ komponent a charakteristik ukazuje skutečnost, že některé komponenty a charakteristiky - vymezené autory jako oborově obecné (např. jasnost, strukturovanost) - mohou nabývat současně povahy oborově specifické (např. strukturovanost z pohledu výuky cizího jazyka). Z oborově specifického pohledu se zdůrazní jiné aspekty, než kdybychom na strukturovanost nahlíželi z obecné či „obor přesahujíci““ perspektivy.

Seznamy oborově obecných charakteristik tak mohou sloužit jako východiska pro rozpracování oborově specifických komponent a charakteristik. Vedle obecných je třeba vymezit i ty, kterými se konkrétní obor liší od jiných oborů. Proto jsme se pokusili sestavit přehled oborově specifických komponent a charakteristik kvalitní výuky cizího jazyka.

Pokud jde o oborově specifické komponenty charakteristiky a indikátory kvality výuky, ty lze nalézt v publikacích z provenience oborových didaktik. Didaktiky jednotlivých oborů se výrazně odlišují v míře rozpracování této problematiky. Zatímco v didaktikách matematiky a přírodních věd je tato problematika rozpracována poměrně detailně, v oblasti jazykového (vč. cizojazyčného) vzdělávání je situace o něco méně příznivá. Pro ilustraci uvádíme několik příkladů klasifikací komponent a charakteristik kvalitní výuky cizího jazyků.

Brown (2005, s. 12-13) zmiňuje v rámci svého oborově specifického modelu dvanáct komponent a charakteristik kvalitní výuky cizího jazyků (tabulka 2). Zmíněné komponenty a charakteristiky jsou však spiše všeobecné a nevychází z modelu kvality výuky cizího jazyka, který by vznikl na základně empirického šetření. Jeho zdrojem jsou spíše teoretické poznatky o osvojování jazyka. 
Tabulka 1 Komponenty a charakteristiky kvalitní výuky podle Helmkeho (2009), Meyera (2004) a Brophyho (2010)

\begin{tabular}{|c|c|}
\hline Helmke $(2009)^{4}$ & $\begin{array}{l}\text { (a) efektivní řízení třídy a využívání času; (b) jasnost } \\
\text { a strukturovanost; (c) konsolidace/upevňování; }{ }^{5} \text { (d) aktivizace; } \\
\text { (e) motivování; (f) podpưrné učební klima; (g) orientace na žáka; } \\
\text { (h) orientace na kompetence; (i) zacházení s heterogenitou; } \\
\text { (j) různorodost nabídky. }\end{array}$ \\
\hline Meyer $(2004)^{6}$ & $\begin{array}{l}\text { (a) jasné strukturování výuky; (b) vysoký podíl využitého času; } \\
\text { (c) podpůrné učební klima; (d) obsahová jasnost; (e) smysluplná } \\
\text { komunikace; (f) rozmanitost metod; (g) individuální podpora; } \\
\text { (h) inteligentní procvičování; (i) transparentní očekávání výkonu; } \\
\text { (j) připravené prostř́edí výuky. }\end{array}$ \\
\hline Brophy $(2010)^{7}$ & $\begin{array}{l}\text { (a) podpůrné učební klima; (b) vytváření př́ležitostí k učení; } \\
\text { (c) korespondence s kurikulem; (d) podpora orientace na/v učení; } \\
\text { (e) soudržnost učiva; (f) kognitivně náročný diskurz; (g) aktivity } \\
\text { k procvičování a aplikaci učiva; (h) podpora žáků při práci } \\
\text { na úlohách; (i) zprostředkování strategií učení; (j) kooperativní } \\
\text { učení; (k) hodnocení orientované na cíle; (l) očekávání výkonu. }\end{array}$ \\
\hline
\end{tabular}

Tabulka 2 Komponenty a charakteristiky kvalitní výuky cizího jazyka podle Browna (2005)

\begin{tabular}{ll}
\hline Brown (2005) & (a) zautomatizování pravidel cizího jazyka; (b) smysluplné učení; \\
(c) předvídání odměňování; (d) vnitřní motivace; (e) strategické \\
vynakládání námahy/času; (f) language ego; (g) sebedůvěra; \\
(h) odvaha; (i) efekt nativního jazyka; (j) mezi-jazyk; \\
(k) komunikační kompetence; (l) propojení jazyk-kultura.
\end{tabular}

Pozn.: Převzato z Browna (2005, s. 12-13)

4 Převod německých termínů do češtiny byl proveden autory této studie. V originále (Helmke, 2009, s. 168-169) byly použity tyto termíny: (a) Effiziente Klassenführung und Zeitnutzung; (b) Klarheit und Strukturiertheit; (c) Konsolidierung und Sicherung; (d) Aktivierung; (e) Motivierung; (f) Lernförderliches Klima; (g) Schülerorientierung; (h) Kompetenzorientierung; (i) Umgang mit Heterogenität; (j) Angebotsvielfalt.

5 Pod touto charakteristikou rozumí Helmke (2009, s. 200) prostor pro opakování a upevňování učiva, pro konsolidaci/upevnění již osvojeného.

6 Převod německých termínů do češtiny byl proveden autory této studie. V originále (Meyer, 2004, s. 23-27) byly použity tyto termíny: (a) Klare Strukturierung des Unterrichts; (b) Hoher Anteil echter Lernzeit; (c) Lernförderliches Klima; (d) Inhaltliche Klarheit; (e) Sinnstiftendes Kommunizieren; (f) Methodenvielfalt; (g) Individuelles Fördern; (h) Intelligentes Üben; (i) Klare Leistungserwartungen; (j) Vorbereitete Umgebung.

7 Převod anglických termínů do češtiny byl proveden autory této studie. V originále (Brophy, 2010, s. 77-104) byly použity tyto termíny: (a) A supportive classroom climate; (b) Opportunity to learn; (c) Curricular alignment; (d) Establishing learning orientations; (e) Coherent content; (f) Thoughtful discourse; (g) Practice and application activities; (h) Scaffolding student's task engagement; (i) Strategy teaching; (j); Co-operative Learning; (k) Goal-oriented assessment; (l) Achievement expectations.

8 Převod anglických termínů do češtiny byl proveden autory této studie. V originále (Brown, 2005, s. 12-13) byly použity tyto termíny: (a) Automaticity; (b) Meaningful learning; (c) The Anticipation of reward; (d) Intrinsic Motivation; (e) Strategic investment; (f) Language ego; (g) Selfconfidence; (h) Risk Taking; (i) The Native language effect; (j) Interlanguage; (k) Communicative competence (l) The Language-culture connection. 
620 něco detailnější a pro náš výzkum lépe uchopitelné jsou komponenty a charakteristiky kvalitní výuky obsažené v modelu CALIFORNIA, které vypracovali Elsnerová a Gießler (2010) a které vychází z jejich empirického výzkumu, který provedli na základních školách (tabulka 3).

Tabulka 3 Komponenty a charakteristiky kvalitní výuky cizího jazyka podle Elsnerové a Gießlera (2010)

\begin{tabular}{ll}
\hline Elsnerová a Gießler $^{9}$ (2010) & (a) komunikace; (b) aktivní učení; (c) jazykové povědomí; \\
& (d) interkulturní porozuméní; (e) zábava; (f) orientace; \\
& (g) opakování; (h) sít’ování; (i) integrace; (j) autenticita. \\
\hline
\end{tabular}

Pozn.: Převzato z Elsnerové a Gießlera (2010)

Dále uvádíme klasifikaci oborově specifických charakteristik pro výuku cizího jazyka dle Fritze a Faistauerové (2008, s. 125-133). Zmíněné dva autory jsme vybrali především proto, že definovali charakteristiky kvalitní výuky cizího jazyka nejobsáhleji a na rozdíl od předešlých autorů nejpodrobněji, a to ze tř́ hledisek: (a) z didaktického hlediska, kde se jedná o všeobecně platné komponenty a charakteristiky kvality výuky cizího jazyka (tabulka 4); (b) z metodického hlediska, které se vztahují na konkrétní podobu výuky cizího jazyka (tabulka 5); (c) z hlediska osvojení cizího jazyka (tabulka 6).

Tabulka 4 Komponenty a charakteristiky kvalitní výuky cizího jazyka z didaktického hlediska10

\begin{tabular}{ll}
\hline $\begin{array}{l}\text { Komponenty } \\
\text { a charakteristiky }\end{array}$ & Obsahové vymezení komponenty a charakteristiky \\
\hline Orientace na žáka & $\begin{array}{l}\text { V centru dění ve výuce je žák, jehož učební potřeby učitelé respektují } \\
\text { např. tak, že zohledňují různé styly učení, specifičnost sociálních, } \\
\text { kulturních a komunikačních předpokladů. } \\
\text { Učení je chápáno jako aktivní proces, v jehož rámci se spojuje již } \\
\text { naučené s novými informacemi. Kooperace je něco více než pouhá } \\
\text { skupinová práce. Je strukturovanější a více orientována na zážitek, } \\
\text { požaduje individuální a společnou zodpovědnost. Žáci pracují společně } \\
\text { na řešení problémů, řeši společné úkoly, spolupráce ve skupině a mezi } \\
\text { partnery je důležitým elementem kooperativního učení, přičemž učitel } \\
\text { přebírá spiše roli moderátora. } \\
\text { Jde o zjištování společných a rozdílných prvků a jejich využivání při } \\
\text { učení se různých cizích jazyků, které jedinec používá k dorozumění se. }\end{array}$ \\
\hline
\end{tabular}

9 Převod anglických termínů do češtiny byl proveden autory této studie. V originále (Elsner \& Gießler, 2010, s. 105) byly použity tyto termíny: (a) Communication; (b) Active learning; (c) Language awareness; (d) Intercultural understanding; (e) Fun; (f) Orientation; (g) Repetition; (h) Networking; (i) Integration; (j) Authenticity.

10 Převod německých termínů do češtiny byl proveden autory této studie. V originále (Fritz \& Faistauer, 2008, s. 125-127) byly použity tyto termíny: (a) LernerInnenzentriertheit; (b) Kooperation; (c) Mehrsprachigkeit; (d) Authentizität; (e) Autonomie. 
Vývoj nástroje pro posuzování vybraných komponent a charakteristik kvality výuky

Tabulka 4 (pokračování)

Autentičnost Využivání výukových materiálů, které: (a) obsahují přirozený běžný

jazyk; (b) navozují běžné „autentické“ situace, se kterými se žák může běžně v komunikaci v cizím jazyce setkat.

Autonomie Výuka, ve které se žáci podílí na určování cílů, učiva a metod výuky. To znamená také to, že jsou žáci postaveni před skutečnost, že jsou také schopni hodnotit zvládnutí společně stanovených cílů.

Pozn.: Převzato z Fritze a Faistauerové (2008, s. 125-127)

Tabulka 5 Komponenty a charakteristiky kvalitní výuky cizího jazyka z metodického hlediska ${ }^{11}$

\begin{tabular}{|c|c|}
\hline Komponenty a charakteristiky & Obsahové vymezení komponenty a charakteristiky \\
\hline Cyklování & $\begin{array}{l}\text { Znamená v širokém smyslu slova opakování. To je } \\
\text { důležitá součást učení. Konkrétně to znamená, že se } \\
\text { ve výuce objeví učivo, které je procvičováno v rámci } \\
\text { rozdílných úkolů a s rozdílným zaměřením. }\end{array}$ \\
\hline Vyrovnanost dovedností & $\begin{array}{l}\text { Snaha o co největší zastoupení řečových } \\
\text { dovedností - u začátečníků více receptivní (čtení, } \\
\text { poslech), u pokročilých produktivní (mluvení, psaní). }\end{array}$ \\
\hline Rozmanitost výuky & $\begin{array}{l}\text { Vedení výuky tak, že dochází ke střídání všech řečových } \\
\text { dovedností a komunikačních kanálů. }\end{array}$ \\
\hline Rozmanitost nabídky textů & $\begin{array}{l}\text { Práce s různými druhy textů, které u žáků vzbuzují } \\
\text { zájem, podporují jejich schopnost pracovat s textem. }\end{array}$ \\
\hline Transparentnost & $\begin{array}{l}\text { Žáci vědí, proč danou aktivitu dělají, jsou jim jasné jak } \\
\text { cíle jednotlivých cvičení, tak i celé vyučovací jednotky. }\end{array}$ \\
\hline Rozmanitost sociálních forem & $\begin{array}{l}\text { Rozmanitost sociálních forem ve vyučování (hromadná, } \\
\text { skupinová, párová, samostatná práce). }\end{array}$ \\
\hline
\end{tabular}

Pozn.: Převzato z Fritze a Faistauerové (2008, s. 127-129)

Tabulka 6 Komponenty a charakteristiky kvalitní výuky cizího jazyka z hlediska osvojení si jazyka12

(a) žáci mají bohatý repertoár jak zažitých výrazů, tak i jazykové povědomí o gramatických normách; (b) orientace na porozumění; (c) výuka se vztahuje také k formální stránce jazyka; (d) rozvíjení implicitních znalostí, aniž by byly upozaděny explicitní znalosti; (e) výuka musí zohledňovat „vnitřní učební plán“ žáků; (f) intenzivní jazykový vstup; (g) př́ležitosti k řečové produkci; (h) interakce je ústřední složkou rozvoje komunikační kompetence v L2; (i) zohledňování individuálních rozdílů mezi žáky.

Pozn.: Převzato z Fritze a Faistauerové (2008, s. 129-133)

11 Převod německých termínů do češtiny byl proveden autory této studie. $V$ originále (Fritz \& Faistauer, 2008, s. 127-128): (a) „Recycling“; (b) Ausgewogenheit der Fertigkeiten; (c) Abwechslung; (d) Textsortenvielfalt; (e) Transparenz; (f) Abwechslung der Sozialformen.

12 Převod německých termínů do češtiny byl proveden autory této studie. V originále (Fritz \& Faistauer, 2008, s. 129-133): (a) Unterricht muss sicherstellen, dass die Lernenden sowohl ein reiches Repertoire an formelhaften Ausdrücke als auch (regelbasiertes) sprachliches Wissen entwickeln; (b) Unterricht muss vor allem verständnisbezogen sein; (c) Unterricht muss sich auch auf die sprachliche Form beziehen; (d) Unterricht soll vor allem implizites Wissen entwickeln helfen, ohne dabei ganz auf explizites Wissen zu verzichten; (e) Unterricht muss den „eingebauten Lehrplan“ der Lernenden berücksichtigen; (f) Erfolgreicher Unterricht braucht intensiven Input; (g) Erfolgreicher Unterricht muss Gelegenheiten schaffen Output zu produzieren; (h) Interaktion ist ein zentraler Bestandteil der Entwicklung einer kommunikativen Kompetenz in der L2; (i) Unterricht muss die individuellen Unterschiede zwischen Lernenden berücksichtigen 
64 Z výše uvedeného výčtu komponent a charakteristik vyplývá, že nebylo prakticky $v$ možnostech a silách autorů této studie obsáhnout v posuzovacím nástroji, který vytvářeli, všechny oborově obecné i oborově specifické komponenty a charakteristiky. Rozhodli jsme se zaměřit na vybrané komponenty a charakteristiky kvality výuky a kvality výuky cizího jazyka, a to z hlediska oborově obecných: (a) motivování, (b) podpưrného učebního klimatu, (c) práce s časem, (d) orientace na cíle výuky a z hlediska oborově specifických, které jsme shrnuli do společné kategorie: učitelův projev. Konkrétní vybrané komponenty a charakteristiky, jejich vymezení a kritéria výběru vysvětlíme v textu dále (kap. 2). Nejdřive však popíšeme, jak jsou tyto komponenty a charakteristiky operacionalizovány a převedeny do indikátorů v posuzovacích systémech $v$ rámci výzkumů kvality výuky cizího jazyka.

Z hlediska výzkumu kvality výuky cizích jazyků je patrně nejvýznamnější studie DESI (Klieme et al., 2008; Helmke et al., 2007). V rámci analýzy výuky zaznamenané na videozáznam se zmíněná studie zabývala (a) popsáním a analýzou reálné výukové praxe, (b) vypracováním bližších indikátorů kvality výuky cizích jazyků, (c) zjištěním stavu komunikace žáků a učitelů. Posuzovací nástroj kvality výuky cizího jazyka použitý v DESI se vztahoval na celou hodinu a zaměřil se na následující komponenty a charakteristiky (a) strukturovanost, (b) vedení třídy, (c) řizení třídy/ práce s časem, (d) podpůrné učební klima, (e) práci s chybou, (f) kvalitu motivování, (g) přiměřenost výuky, (h) učitelův projev, které jsou popsány, stejně jako jejich indikátory $v$ tabulce 7 .

\subsection{Shrnutí a diskuse}

Z výše uvedeného přehledu je patrné, že v pozadí systémů komponent a charakteristik kvality výuky stojí odlišné cílové hodnoty odkazující k odlišným kritériím kvality. Jinak řečeno, ptáme-li se po kvalitě výuky, je třeba uvažovat o tom, vzhledem k jakým cílům mají být určité výukové postupy účinné. Podle současné generace kurikulárních dokumentů by kvalitní výuka v základních školách měla přispívat k rozvoji klíčových kompetencí na úrovni obecných vzdělávacích cílů a směřovat k dosažení určité úrovně komunikační kompetence $v$ př́slušném cizím jazyce na úrovni cílů oborových. Výzkumy nicméně naznačují, že zmíněným vizím je realita ve školách přece jen poněkud vzdálená (za výuku angličtiny viz např. Šebestová, 2011). Vezmeme-li navíc v úvahu stabilitu výukových postupů, resp. jejich rezistenci vưči změně, dobereme se závěru, že snaha odvozovat nástroje posuzování kvality výuky z projektovaného (psaného) kurikula může být tím více zavádějící, čím větší je v praxi rozpor mezi kurikulem projektovaným a realizovaným. Nástroj, který by byl validní s ohledem na psané kurikulum, by $v$ našem případě stěží mohl být validní s ohledem na kurikulum realizované, tj. na to, co se děje $v$ reálné výuce (podrobněji $k$ tomu viz Janík, Slavík, \& Janko, 2013). Při vývoji našeho posuzovacího nástroje nehraje tudiž ohled na projektované kurikulum významnou roli. Navrhovaný nástroj, v jehož teoreticko-metodologickém zázemí stojí spíše tradice didaktická než tradice kurikulární, mưže posloužit k analýze současného stavu výuky. 
Tabulka 7 Komponenty a charakteristiky a indikátory - studie DESI

Komponenty/charakteristiky kvality Indikátory

výuky cizího jazyka ${ }^{13}$

(a) Strukturovanost

(a) systematicky, věcně a logicky seřazená struktura hodiny; (b) transparentnost hodiny; (c) shrnutí;

(d) aktivizace

(b) Vedení třídy

(a) orientace na žáka

(c) Řízení třídy/Práce s časem

(a) orientace na úkoly; (b) plánování výuky a časový management; (c) nerušená výuka

(d) Podpůrné učební klima

(a) sociální klima, srdečnost, vřelost; (b) humor

(e) Práce s chybou

(a) učitelův přístup k chybám žáků; (b) přístup k chybám ze strany žáků

(f) Kvalita motivování

(a) učitelův zájem o předmět; (b) zájem žáků o výuku;

(c) propojení s praxí, životem; (d) povzbuzování žáků k aktivnímu zapojení ve výuce

(g) Přiměřenost výuky

(a) variace/adaptabilita výuky; (b) náročnost výuky (tempo výuky)

(h) Učitelův projev ${ }^{14}$

(a) jasnost (koherence učitelových výkladů - obsahový aspekt; výstižnost učitelovy mluvy během výkladu - jazykový aspekt); (b) obsahová jasnost;

(c) výslovnost; (d) jistota ve slovní zásobě;

(e) gramatická jistota; (f) specifické verbální návyky

Pozn.: Upraveno podle Helmke et al. (2007, s. 2-27)

Z dosavadního textu je dále patrné, že prezentované systémy (kap. 1.2) se odlišují v tom, do jaké míry jsou $v$ nich zastoupeny obecně oborové komponenty a charakteristiky ( $v$ našem viz odkazy k Helmkemu, 2009; Meyerovi, 2004; Brophymu 2010) versus oborově specifické komponenty a charakteristiky kvality výuky ( $v$ našem textu viz odkazy k Brownovi, 2005; Elsnerové a Gießlerovi, 2010; Fritzovi a Feistauerové, 2008 a Helmkemu et al., 2007). Při vývoji posuzovacího nástroje kvality výuky cizího jazyka jsme se pokoušeli zohlednit jak komponenty a charakteristiky oborově obecné, tak oborově specifické (viz dále).

\section{Vývoj a tvorba nástroje pro posuzování kvality výuky cizího jazyka}

Hlavním cílem výzkumu zpracovávaného prvním autorem této studie v rámci disertační práce bylo navrhnout nástroj pro posuzování kvality výuky cizího jazyka

13 Převod německých termínů do češtiny byl proveden autory této studie. V originále (Helmke et al., 2007, s. 2-27) byly použity tyto termíny: (a) Strukturiertheit; (b) Lenkung; (c) Klassenführung und Zeitnutzung; (d) Beziehungsqualität/Lernförderliches Klima; (e) Fehlerklima; (f) Motivierungsqualität; (g) Variation/Passung; (h) Lehrersprache.

14 V této oblasti kvality výuky šlo o kvalitu učitelova vyjadřování v cizím jazyce (v případě DESI šlo o anglický jazyk). 
66 z hlediska: (a) motivování, (b) podpůrného učebního klimatu, (c) práce s časem, (d) orientace na cíle výuky, (e) učitelova projevu. Důležitá kritéria pro výběr těchto komponent a charakteristik byla tato: (a) z hlediska kvality výuky jsou považovány za důležité, (b) oblasti jsou ve výuce posuzovatelné (Klieme et al., 2008, s. 338).

Při hledání vhodného nástroje pro posuzování výuky ve vytyčených oblastech kvality výuky jsme vycházeli z prací Helmkeho (2009, s. 289-290), Kliemeho et al. (2008) a Hugenerové (2006, s. 46). Zmínění autoři doporučují pro posuzování kvality výuky využívat nástroje s ratingovým systémem. Pomocí těchto nástrojů posuzují obvykle dva posuzovatelé míru zastoupení konkrétních charakteristik kvality (např. jasnost) ve výuce. Podle Hugenerové (2006, s. 46) a Kliemeho et al. (2008, s. 345) by měly být tyto nástroje $v$ praxi aplikovány především na celé vyučovací jednotky. Jedná se tedy o tzv. holistické či globální posuzování. Stejně je tomu i v případě našeho posuzovacího nástroje. Pro jeho návrh byly inspirací zdroje z české (Žák, 2006) a především ze zahraniční literatury (Helmke et al., 2007; Klieme et al., 2008; Seidel et al., 2003). Dílčím cílem v rámci vývoje nástroje bylo ověření posuzovacího nástroje na vybraném vzorku hodin a především jeho postupné zdokonalování $\mathrm{k}$ tomu, aby mohl být následně použit $\mathrm{v}$ připravované videostudii. ${ }^{15}$

$\checkmark$ textu dále vymezíme vybrané oborově obecné a oborově specifické komponenty a charakteristiky našeho posuzovacího nástroje, představíme podobu škály, slovního vymezení hodnot indikátorů na škále a představíme konečnou podobu našeho posuzovacího nástroje.

\subsection{Vymezení oborově obecných a oborově specifických komponent a charakteristik pro posuzovací nástroj kvality výuky cizího jazyka}

V následující podkapitole se budeme věnovat popisu a vymezení vybraných komponent a charakteristik kvalitní výuky cizího jazyka, které jsou obsaženy $v$ našem posuzovacím nástroji: (a) motivování, (b) podpưrné učební klima, (c) práce s časem, (d) orientace na cíle výuky, (e) učitelův projev. Zmíněné komponenty a charakteristiky kvality výuky, vycházející ze zahraničních a domácích výzkumů, jsou inspirovány př́stupy, které jsme zmínili výše (kap. 1.2).

\section{Motivování}

Podle některých autorů (srov. Helmke, 2003) patří motivování mezi jednu z hlavních komponent / charakteristik kvalitní výuky. Konkrétně je chápána jako „dostatečně podnětná hodnota pro zabývání se učivem“ (Helmke, 2003, s. 74). Motivování tak hraje v učení žáků a ve výuce významnou roli. Uvedený autor rozlišuje čtyři

15 Videozáznamy 28 hodin výuky německého jazyka byly pořizeny v rámci IVŠV videostudie, která proběhla na jaře 2012 na náhodně vybraných školách v Jihomoravském kraji. Náš posuzovací nástroj je však koncipován tak, že mủže být využit jak pro posuzování kvality výuky německého jazyka, tak i pro posuzování kvality výuky jiných cizích jazyků (např. anglický jazyk). 
indikátory motivování: ${ }^{16}$ (a) využití učiva v reálném životě, (b) učitelovo očekávání,

(c) učitel jako model, (d) kognitivní konflikty a zvídavost jako motory učení. Tyto indikátory jsou podrobně popsány $v$ tabulce 8 .

Tabulka 8 Motivování: indikátory a jejich obsahové vymezení

\begin{tabular}{ll}
\hline Indikátory & Obsahové vymezení indikátorů \\
\hline Využití učiva v reálném životě & $\begin{array}{l}\text { Jde především o koncepty jako autenticita výuky, napojení } \\
\text { na běný život, přímá návaznost na aktuální dění ve třídě. }\end{array}$ \\
Učitelovo očekávání & $\begin{array}{l}\text { Jde o to, na co se učitel ve výuce svého předmětu zaměřuje } \\
\text { a co považuje za dưležité (např. psaní textů nebo spontánní } \\
\text { mluvení). }\end{array}$ \\
Učitel jako model & $\begin{array}{l}\text { Jde o přístup učitele k výuce, přístup učitele k jeho předmětu, } \\
\text { míru jeho entuziasmu a angažovanosti ve výuce. }\end{array}$ \\
Kognitivní konflikty a zvídavost & $\begin{array}{l}\text { Jde o procesy asimilace (u nově osvojovaných znalostí snaha } \\
\text { o zařazení do již existující struktury) a akomodace (změna } \\
\text { struktury znalostí na základě neslučitelnosti s již existujícími). }\end{array}$ \\
\hline
\end{tabular}

Pozn.: Převzato z Helmke (2009, s. 217-219)

\section{Podpưrné učební klima}

Helmke (2009, s. 220) definuje tuto komponentu a charakteristiku kvality výuky jako klima, „ve kterém je učení žáků ulehčeno, ovlivňováno kladným způsobem a podporováno“. Uvedený autor zmiňuje v tomto kontextu i indikátory klimatu ve výuce podporujícího učení:17 (a) konstruktivní zacházení s chybami, (b) přiměřený čas čekání na odpověd', (c) uvolněná učební atmosféra, (d) redukce strachu inhibujícího výkon. Všechny tyto komponenty jsou podrobně obsahově vymezeny v tabulce 9.

Tabulka 9 Podpůrné učební klima: indikátory a jejich obsahové vymezení

\begin{tabular}{ll}
\hline Indikátory & Obsahové vymezení indikátorů \\
\hline Přístup k chybám & Pro kvalitu výuky je důležité, že (a) chyby nevedou \\
& k zahanbování; (b) chyby nejsou spojovány jen \\
& s výtkami a jinými negativními důsledky, nýbrž jsou \\
& brány jako přirozená součást procesu učení. \\
Přiměřený čas čekání na odpověd' & Rozlišuje se dvojí způsob čekání na odpověd': \\
& (a) časový úsek poté, co učitel položí žákovi otázku; \\
& (b) čas mezi poupravenou odpovědí žáka a reakcí \\
& učitele.
\end{tabular}

16 Převod německých termínů do češtiny byl proveden autory této studie. V originále (Helmke, 2009, 217-219) byly použity tyto termíny: (a) Die Rolle der Lebenswelt; (b) Die Rolle der Lehrerserwartungen; (c) Lehrperson als Modell; (d) Kognitive Konflikte und Neugier als Motoren des Lernens.

17 Převod německých termínů do češtiny byl proveden autory této studie. V originále (Helmke, 2009, s. 220-229) byly použity tyto termíny: (a) Konstruktiver Umgang mit Fehlern; (b) Wartezeit; (c) Entspannte Lernatmosphäre; (d) Abbau hemmender Leistungsangst 
Tabulka 9 (pokračování)

\begin{tabular}{ll}
\hline Indikátory & Obsahové vymezení indikátorů \\
\hline Uvolněná učební atmosféra & Pro výuku je vhodné, když je atmosféra ve výuce \\
& uvolněná, když je často ve výuce veselo, když je učitel \\
& schopen udělat si sám ze sebe legraci, když je učitel \\
& schopen povznést se a žertovat na svou adresu. \\
Redukce strachu inhibujícího výkon & Výuka beze strachu je charakterizována: \\
& (a) vytvářením jistoty (žáci nejsou podrobeni častým \\
& změnám, ví, co mohou očekávat, hodnocení výkonu \\
& je transparentní); (b) klimatem důvěry mezi žáky \\
& a učitelem - přátelství, vřelost, váženost; (c) diskusí \\
& na téma strachu ve výuce - strach není bagatelizován; \\
& (d) individualizovanou povzbuzující zpětnou vazbou, \\
& orientací na individuální normy.
\end{tabular}

Pozn.: Převzato z Helmkeho (2009, s. 220-229)

\section{Práce s časem}

Touto komponentou a charakteristikou kvalitní výuky je míněno efektivní využití času výuky prostřednictvím dobrého plánování k dosažení vytyčeného cíle. Odborná literatura (Helmke, 2009, s. 185) v této souvislosti zmiňuje tzv. časové ztráty (Zeitdiebe), které se ve výuce objevují nejčastěji a jsou v kvalitní výuce nežádoucí. Mezi takové ztráty patří: (a) nepřesný začátek hodiny, (b) dřivější ukončení hodiny, (c) dlouhé přechody mezi fázemi hodiny,(d) bezdůvodně dlouhé pauzy při čekání na odpověd', (e) problémy při obsluze techniky ve výuce, (f) administrativní úkony.

\section{Orientace na cíle výuky}

Orientace na cíle výuky je chápána jako žákův záchytný bod ve výuce, díky němuž se může ve výuce a v událostech, které v rámci ní probíhají, lépe zorientovat. Podle Trepkeové et al. (2003, s. 201-202) jde především o: (a) oznámení cílů na začátku hodiny, (b) navázání na cíle v průběhu hodiny, (c) shrnutí cílů jednotlivých fází hodiny, (d) shrnutí obsahu hodiny na konci výuky s ohledem na vytyčené cíle.

\section{Učitelův projev}

Tato oborově specifická komponenta/charakteristika vztahující se k učitelovu projevu v cizím jazyce vychází z Helmkeho $(2003,2009)$ charakteristiky jasnosti. Vymezení pojmu jasnost je obtižné, protože v určitých dimenzích (cílová, obsahová, organizační apod.) nabývá pojem jasnost odlišných významů (např. jasnost cílů). V našem př́padě však při definování pojmu jasnost vycházíme z Helmkeho (2003, s. 60), který tuto komponentu a charakteristiku kvality výuky uplatňuje především při posuzování učitelových vyjádření (výklad, vysvětlování, otázky), méně u žáky řízených forem výuky (skupinová práce). Zahrnuje čtyři indikátory: (a) akustická jasnost (srozumitelnost), (b) jazyková jasnost (pregnantnost), (c) obsahová jasnost (koherence), (d) oborová jasnost (korektnost). Každý z těchto indikátorů uvedené komponenty a charakteristiky je podrobně obsahově vymezen v tabulce 10. 
Tabulka 10 Jasnost: indikátory a jejich obsahové vymezení18

\begin{tabular}{|c|c|}
\hline Indikátory & Obsahové vymezení indikátorů \\
\hline Akustická jasnost (srozumitelnost) & $\begin{array}{l}\text { Akustická jasnost je vázána na charakteristiky jazyka } \\
\text { a mluveného projevu, tzn. na přiměřené rozvinutí } \\
\text { síly hlásek, výšek tónů, rychlosti mluvení, pauz, } \\
\text { artikulace, modulace, barvy hlasu a také rozlišení, zda } \\
\text { se mluví dialektem, nebo spisovným jazykem. }\end{array}$ \\
\hline Jazyková jasnost (pregnantnost) & $\begin{array}{l}\text { Jazyková jasnost se týká jasnosti a zřetelnosti } \\
\text { jednotlivých jazykových formulací, nejčastěji } \\
\text { jednotlivých vět (jasnost stavby věty). Nejde zde } \\
\text { o obsah, ale výlučně o jazykové podání. Jde o to, } \\
\text { jestli je učitel schopen jazykem objasnit to, co mu } \\
\text { přijde podstatné. Výkony žáků jsou tím menší, čím } \\
\text { vyšší je frekvence výskytu následujících charakteristik } \\
\text { v řečovém projevu učitele: (a) nejasné a nejisté výrazy } \\
\text { (snad, řekl bych, do jisté míry, atd.); } \\
\text { (b) nesprávná gramatika nebo slovní zásoba (užívání } \\
\text { nevhodných či nesprávných synonym, nedokončení } \\
\text { vět nebo nesprávné formulování vět); (c) přerušování } \\
\text { plynulosti výuky (např. prostřednictvím nepodstatných } \\
\text { komentářů, odbočování od probíraného tématu, } \\
\text { prezentací odborných obsahů v nesprávné fázi hodiny); } \\
\text { (d) prostředky s nulovým významem (parazitní výrazy) } \\
\text { jako ehm, no, ok, hm, že? no?, ne? ok? nebo jiné } \\
\text { specifické jazykové návyky). }\end{array}$ \\
\hline Obsahová jasnost (koherence) & $\begin{array}{l}\text { Obsahová jasnost se týká výkladů a jejich logické } \\
\text { výstavby a návaznosti. }\end{array}$ \\
\hline Oborová jasnost (korektnost) & $\begin{array}{l}\text { Oborová jasnost (výslovnost, variace stylu, intonace } \\
\text { a gramatická kompetentnost) má zásadní význam } \\
\text { především v rámci výuky cizích jazyků. Učitelova řeč } \\
\text { totiž ve výuce cizího jazyka přestavuje model, který je } \\
\text { žáky často napodobován. }\end{array}$ \\
\hline
\end{tabular}

Pozn.: Převzato z Helmke (2009, s. 191-193)

\section{2 Škála a slovní vymezení hodnot na škále}

Škály použité v posuzovacím nástroji a jejich kvantifikace (tabulka 11) jsou inspirovány pracemi Kliemeho et al. (2008), Helmkeho et al. (2007), Seidelové et al. (2003) a Žáka (2006). Stejně jako u uvedených posuzovacích nástrojů, tak i v našem nástroji jsou posuzovatelé nuceni rozhodnout se bud' pro kladné hodnocení (pro stupně,+++ ), negativní hodnocení (pro stupně -, --) nebo pro možnost $\mathrm{N}^{19}$.

18 Převod německých termínů do češtiny byl proveden autory této studie. V originále (Helmke, 2009, s. 191) byly použity tyto termíny: (a) akustisch (Verstehbarkeit); (b) sprachlich (Prägnanz); (c) inhaltlich (Kohärenz); (d) fachlich (Korrektheit).

19 V našem posuzovacím nástroji chápeme možnost $\mathrm{N}$ u některých indikátorů jako nelze zaškrtnout ( $v$ prrípadě, že je míra daného indikátoru na škále dostatečně vymezená a posuzovatel je nucen 
Tabulka 11 Škála a její kvantifikace

\begin{tabular}{ccccc}
\hline++ & + & - & -- & $\mathrm{N}$ \\
\hline 4 & 3 & 2 & 1 & 0 \\
\hline
\end{tabular}

Každá hodnota indikátoru dané komponenty/charakteristiky, z nichž se posuzovací nástroj skládá, je na škále slovně vymezena. Příklad slovního vymezení hodnot konkrétního indikátoru v předkládaném posuzovacím nástroji je uveden v tabulce 12.

Tabulka 12 Slovní vymezení hodnot indikátoru na škále - příklad

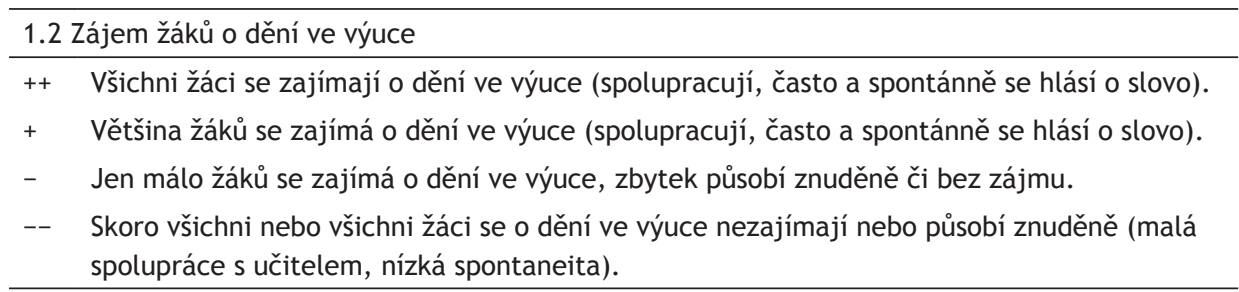

V textu dále popíšeme finální verzi posuzovacího nástroje kvality výuky cizího jazyka a úskalí, na která jsme během vývoje narazili, a výsledky pilotáže finální verze.

\subsection{Finální verze posuzovacího nástroje}

Během vývoje jsme byli nuceni náš nástroj několikrát upravit. Vzhledem $k$ tomu, že pozorovací nástroj kvality výuky cizího jazyka nebyl pro účely našeho výzkumu ve vyhovujícím pojetí k dispozici, musely být zahraniční pozorovací nástroje modifikovány do požadované formy. To bylo spojeno s pojmovým vymezením komponent a charakteristik indikátorů a jejich slovního vymezení prostřednictvím hodnot na škále. Nemalým úskalím bylo nalezení vhodných českých ekvivalentů pro cizojazyčné termíny. Dokladem dlouhého procesu vývoje jsou předešlé tři verze posuzovacího nástroje. Tyto verze jsou popsány v jiných publikacích (Zlatníček, 2011a; Zlatníček, 2011b; Zlatníček 2011c; Zlatníček, 2011d).

Na tomto místě představíme pouze finální verzi posuzovacího nástroje pro posuzování vybraných komponent/charakteristik kvality výuky cizího jazyka (tabulka 13). Ta se skládá z komponent a charakteristik oborově obecných: (a) motivování, (b) podpůrné učební klima, (c) práce s časem, (d) orientace na cíle výuky, a komponenty a charakteristiky oborově specifické, jíž je učitelův projev. Jak již bylo řečeno výše, tyto oblasti vychází z oborově obecných a oborově specifických komponent a charakteristik kvality výuky a kvality výuky cizího jazyka, které jsme vymezili v kapitole 1.2 .

rozhodnout se jen mezi kladnými ++, + a negativními hodnotami --, -) a u některých indikátorů jako nelze posoudit ( $v$ př́padě, že posuzovatel míru daného indikátor u ve výuce př́i posuzování nezaznamenal). 
Komponenta motivování je reprezentována oborově obecnými indikátory, pro jejichž vznik byly inspirací indikátory popsané v ratingu Žáka (2006) a Helmkeho et al. (2007): (a) učitelův zájem o předmět; (b) zájem žáků o dění ve výuce; (c) využití zájmu žáků; (d) návaznost výuky na praxi, život; (e) povzbuzování žáků k aktivnímu zapojení ve výuce; (f) poukázání ve výuce na souvislosti němčiny s jinými cizími jazyky (vícejazyčnost). ${ }^{20}$

Komponenta podpůrné učební klima je reprezentována především indikátory definovanými $v$ ratingu Helmkeho et al. (2007). Na rozdíl od posuzovacího nástroje zmíněného autora však $v$ našem posuzovacím nástroji chybí indikátor humor. Během pilotáže předešlých verzí jsme totiž na základě měření inter-rater reliability $v$ př́padě zmíněného indikátoru zjistili, že tento indikátor je s ohledem na subjektivnost posuzování velice problematický. Především proto, že posuzovatelé nebyli $s$ to se často shodnout $v$ tom, zda je humor učitele upřímný a zda byl humor učitele $\checkmark$ pozorovaných hodinách vtipný i pro posuzovatele. Komponenta podpůrné učební klima byla $v$ průběhu vývoje nástroje doplněna o dva oborově obecné indikátory kvality $v$ dané oborově obecné komponentě: (a) příležitost žákủ k vyjadřování se během výuky, (b) atmosféra ve výuce. Tyto dva oborově obecné indikátory byly autorem pozorovacího nástroje vytvořeny na základě poznatků z odborné literatury (srov. tabulka 9). Komponenta podpůrné učební klima je reprezentována následujícími indikátory: (a) učitelovo chování k žákům (zájem, srdečnost, vřelost), (b) učitelův přistup k chybám žáků, (c) přistup k chybám ze strany žáků, (d) príležitost žáků k vyjadřování se během výuky, (e) navozování přijemné atmosféry.

Indikátory oborově obecné komponenty práce s časem vychází z posuzovacího nástroje Helmkeho et al. (2007). V našem posuzovacím nástroji je tato komponenta reprezentována následujícími indikátory: (a) využití času pro vyučovaný predmět ${ }^{21}$, (b) management času22, (c) nerušená výuka23.

Indikátory oborově obecné komponenty orientace na cíle výuky byly charakterizovány na základě části ratingu Seidelové et al. (2003). V našem posuzovacím nástroji je tato komponenta reprezentována následujícími indikátory: (a) oznámení cílů na začátku hodiny, (b) navázání na cíle výuky $v$ průběhu hodiny ${ }^{24}$, (c) shrnutí cílů jednotlivých fází hodiny, (d) shrnutí obsahu hodiny na konci výuky s ohledem na vytyčené cíle. Během vývoje posuzovacího nástroje musely být při převodu do českého jazyka indikátory zmíněné komponenty jazykově několikrát modifikovány.

Oborově specifická komponenta učitelův projev se týká pouze projevu učitele v cizím jazyce. Zastáváme totiž názor, že pokud chceme posuzovat kvalitu cizího

20 Indikátor poukázání ve výuce na podobnosti němčiny s jinými cizími jazyky vychází z oborově specifické komponenty a charakteristiky podpora vícejazyčnosti (Fritz \& Faistauer, 2008, s. 125-133).

21 Pod indikátorem využití času pro předmět rozumíme, do jaké míry se věnoval výuce předmětu a ne jiným aktivitám (např. zdlouhavé vyplňování třídní knihy, odbočování od probíraného tématu)

22 Pod indikátorem management času rozumíme míru časové neplánovanosti aktivit ve výuce (např. hektický průběh aktivit či přerušení jednotlivých aktivit vinou nedostatečného času).

23 Pod indikátorem nerušená výuka rozumíme míru narušování výuky žáky a z toho plynoucí ztráty času s disciplinárními zásahy učitele.

24 Pod indikátorem navázání na cíle výuky v průběhu hodiny rozumíme, do jaké míry se učitel ve výuce drží na začátku hodiny stanovených cílů. 
72 jazyka, měla by se kvalitní výuka vyznačovat mj. tím, že se v ní mluví především v cizím jazyce - učitele vnímáme jako vzor (model) a iniciátora komunikace v cizojazyčné výuce. Na to upozorňují i Helmke a Schrader (2006, s. 6) s odkazem na studii DESI s tím, že výsledky žáků ve výuce cizího jazyka, kde se mluví častěji v mateřském jazyce, jsou dle výsledků zmíněné studie podstatně horší, než u těch žáků, kteří se účastní výuky, kde se mluví cizím jazykem často.

V našem posuzovacím nástroji je tato komponenta reprezentována následujícími indikátory: (a) obsahová jasnost výkladů učiva $v$ cizím jazyce (koherence) ${ }^{25}$, (b) odborná jasnost výkladů učiva v cizím jazyce (korektnost)26, (c) výstižnost učitelova projevu při komunikaci s žáky27, (d) výslovnost, (e) slovní zásoba28, (f) gramatická správnost, (g) specifické vyjadřovací návyky29.

Tabulka 13 Finální verze posuzovacího nástroje - komponenty/charakteristiky a indikátory

\begin{tabular}{ll}
\hline Komponenty/charakteristiky & Indikátory \\
\hline 1. Motivování & 1.1 Učitelův zájem o předmět \\
& 1.2 Zájem žáků o dění ve výuce \\
& 1.3 Využití zájmu žáků \\
& 1.4 Návaznost výuky na praxi, život \\
& 1.5 Povzbuzování žáků k aktivnímu zapojení se ve výuce \\
& 1.6 Poukázání ve výuce na souvislosti němčiny s jinými cizími \\
& jazyky (vícejazyčnost) \\
& 2.1 Učitelovo chování k žákům (zájem, srdečnost, vřelost) \\
& 2.2 Učitelův přistup k chybám žáků \\
& 2.3 Přístup k chybám ze strany žáků \\
& 2.4 Příležitost žáků k vyjadřování se během výuky \\
& 2.5 Navozování příjemné učební atmosféry \\
& 3.1 Využití času pro vyučovaný předmět \\
& 3.2 Časový management \\
& 3.3 Nerušená výuka \\
\hline 3. Práce s časem &
\end{tabular}

25 Pod indikátorem obsahová jasnost výkladů učiva v cizím jazyce (koherence) rozumíme to, do jaké míry jsou učitelovy výklady učiva v cizím jazyce z hlediska obsahu vždy jasně členěné, strukturované, a tím i srozumitelné.

26 Pod indikátorem odborná jasnost výkladů učiva v cizím jazyce (korektnost) rozumíme to, do jaké míry byly učitelovy výklady učiva v cizím jazyce správné z hlediska oboru, který vyučuje.

27 Pod indikátorem výstižnost učitelova projevu při komunikaci s žáky rozumíme to, do jaké míry je učitel během hodiny schopen při komunikaci s žáky (např. zadávání úkolů, vysvětlování aktivit) vyjádřit v cizím jazyce vše podstatné bez pomáhání si mateřským jazykem.

28 Pod indikátorem slovní zásoba rozumíme míru jistoty učitele v jeho slovní zásobě v cizím jazyce (při jeho projevu v cizím jazyce).

29 Pod tímto indikátorem rozumíme: (a) nejasné a nejisté výrazy (snad, řekl bych, do jisté míry, celkem vzato, co já vím, eventuálně, abych tak řekl, atd.); (b) přerušování plynulosti výuky nepodstatnými komentáři; (c) prostředky s nulovým jazykovým významem (parazitní výrazy) jako ehm, no, ok, hm, že? no?, ne? ok? nebo jiné specifické jazykové návyky. 


\begin{tabular}{|c|c|c|}
\hline \multirow[t]{4}{*}{ 4. Orientace na cíle výuky } & \multicolumn{2}{|c|}{ 4.1 Oznámení cílů na začátku hodiny } \\
\hline & \multicolumn{2}{|c|}{ 4.2 Navázání na cíle v průběhu hodiny } \\
\hline & \multicolumn{2}{|c|}{ 4.3 Shrnutí cílů jednotlivých fází hodiny } \\
\hline & \multicolumn{2}{|c|}{$\begin{array}{l}4.4 \text { Shrnutí obsahu hodiny na konci výuky s ohledem na vytyčené } \\
\text { cíle. }\end{array}$} \\
\hline \multirow[t]{7}{*}{ 5. Učitelův projev } & 5.1 Jasnost & $\begin{array}{l}\text { 5.1.1 Obsahová jasnost } \\
\text { výkladů učiva v cizím } \\
\text { jazyce (koherence) }\end{array}$ \\
\hline & & $\begin{array}{l}\text { 5.1.2 Odborná jasnost } \\
\text { výkladů učiva v cizím } \\
\text { jazyce (korektnost) }\end{array}$ \\
\hline & & $\begin{array}{l}5.1 .3 \text { Výstižnost učitelova } \\
\text { projevu při komunikaci } \\
\text { s žáky }\end{array}$ \\
\hline & \multicolumn{2}{|c|}{5.2 Výslovnost } \\
\hline & \multicolumn{2}{|c|}{ 5.3 Slovní zásoba } \\
\hline & \multicolumn{2}{|c|}{ 5.4 Gramatická správnost } \\
\hline & \multicolumn{2}{|c|}{ 5.5 Specifické vyjadřovací návyky } \\
\hline
\end{tabular}

\subsection{Pilotáž finální verze posuzovacího nástroje - průběh a výsledky}

V rámci pilotáže finální verze nástroje pro posuzování kvality výuky cizího jazyka jsme pozorovali videozáznamy čtyř hodin němčiny. To představuje přibližně jednu desetinu souboru hodin, které budou analyzovány $v$ rámci hlavního šetření, a odpovídá to standardům kladeným na proces dosahování shody mezi posuzovateli (srov. Najvar et al., 2011, s. 43). Zjišt'ovali jsme míru absolutní shody mezi posuzovateli a pro zjištění inter-rater reliability jsme vypočítali koeficient Cohenova Kappa (tabulka 14). Cílem pilotáže bylo především vyzkoušení konečné verze posuzovacího nástroje před jeho použitím pro hlavní šetření v rámci disertačního výzkumu prvního autora studie (posuzování celého souboru videozáznamu hodin výuky německého jazyka). Pokud vycházíme z toho, že odborná literatura považuje za přijatelnou hodnotu Cohenovy Kappy vyšší než 0,70 (Bortz \& Döring, 2002, s. 277), splňuje finální verze posuzovacího nástroje tuto podmínku ve všech posuzovaných hodinách (tabulka 14).

Tabulka 14 Výsledky pilotáže finální verze posuzovacího nástroje

\begin{tabular}{lcc}
\hline Hodina & $\begin{array}{c}\text { Absolutní shoda (\%) mezi } \\
\text { posuzovateli (1) a (2) }\end{array}$ & $\begin{array}{c}\text { Cohenova Kappa } \\
\text { posuzovatel (1) a (2) }\end{array}$ \\
\hline Zkušební A & 92 & 0,848 \\
Zkušební B & 92 & 0,899 \\
Zkušební C & 92 & 0,949 \\
Zkušební D & 96 & 0,949 \\
\hline
\end{tabular}


Cílem tohoto textu bylo představit vývoj nového nástroje pro posuzování vybraných komponent/charakteristik kvality výuky a jeho aplikaci v oblasti výuky cizího jazyka. Mezi vybrané oborově obecné komponenty/charakteristiky patří: (a) motivování, (b) podpưrné učební klima, (c) práce s časem, (d) orientace na cíle výuky a mezi oborově specifické komponenty a charakteristiky patří: (e) učitelưv projev. Oborově specifická komponenta posuzovacího nástroje učitelův projev se týká pouze projevů učitele v cizím jazyce. Zmíněné komponenty a charakteristiky vycházejí z oborově specifických a obecných komponent a charakteristik a obsahují relevantní indikátory kvality výuky cizího jazyka, které jsou pro daný stupeň škály slovně vymezeny.

Během vývoje posuzovacího nástroje vybraných komponent a charakteristik kvality výuky cizího jazyka jsme narazili na mnohá úskalí. Jak zmiňujeme v úvodu, výzkum v oblasti kvality výuky je orientován spíše na předměty jako matematika a fyzika a mnohem méně na cizí jazyky. Posuzovací nástroj tak nebyl pro účely výzkumu ve vyhovujícím pojetí k dispozici, musely být proto existující posuzovací nástroje modifikovány do požadované formy. Z toho vyplývaly problémy. Výzkumy (a) byly zaměřeny oborově specificky, bylo tedy obtížné najít správné komponenty a charakteristiky, které by mohly odpovídat i specifikům jazykové výuky. Problémy se (b) týkaly jazykových formulací. Vzhledem k tomu, že přeložené pasáže (zvláště pro posuzovací nástroj) neměly často korespondenci v užívaných českých termínech nebo působily dosti uměle a nepřirozeně, což zpočátku značně ztěžovalo posuzovatelům jejich práci. $Z$ tohoto důvodu došlo několikrát $k$ jazykové úpravě. Týkalo se to nejen označení posuzovaných komponent a charakteristik kvality výuky cizího jazyka, ale především posuzovaných indikátorů a jejich slovního vymezení hodnot na škále.

Nicméně, shrneme-li výsledky poslední pilotáže (tabulka 14), splnila finální varianta posuzovacího nástroje požadavky na inter-rater reliabilitu u všech posuzovaných hodin a ve srovnání s předešlými variantami byla nejúspěšnější a nejspolehlivější. Přesto jsme si vědomi toho, že námi navržený nástroj nepokrývá všechny komponenty / charakteristiky relevantní pro kvalitu výuky cizího jazyka, a že tudíž pokrývá jen část jejich širokého spektra. Výzvou pro další vývoj v této oblasti proto je další rozšiřování tohoto nástroje, popř. vytváření nástrojů komplementárních.

\section{Literatura}

Bortz, J., \& Döring, N. (2002). Forschungsmethoden und Evaluation für Human- und Sozialwissenschaftler. Heidelberg: Springer.

Brophy, J. (2010). Was wissen wir darüber, wie guter Unterricht gelingt? In G. Eikenbusch, \& H. W. Heymann et al., Was wissen wir über guten Unterricht? (s. 77-104). Hamburg: Bergmann + Helbig Verlag.

Brown, D. H. (2005). English Language Teaching in the post Method Era: Toward Better Diagnosis, Treatment and Assessment. In C. J. Richards \& W. A. Renandya et al., Methodology in Language Teaching. An Anthology of Current Practice (s. 9-18). Cambridge: Cambridge University Press. 
Elsner, D., \& GieBler, R. (2011). Quality Teaching: Kriterien zur Planung und Beurteilung „guten Englischunterrichts“ - Beispiel Wortschatzarbeit. In K. O. Bauer \& N. Logemann (Eds.), Unterrichtsqualität und fachdidaktische Forschung: Modelle und Instrumente zur Messung fachspezifischer Lernbedingungen und Kompetenzen (s. 101-124). Münster: Waxmann.

Fend, H. (1998). Qualität im Bildungswesen. Schulforschung zu Systembedingungen, Schulprofilen und Lehrerleistungen. Weinheim: Juventa.

Fritz, T., \& Faistauer, R. (2008). Prinzipien eines Sprachunterrichts. In E. Bogenreiter-Feigl (Eds.), Paradigmenwechsel? Sprachenlernen im 21. Jahrhundert: Szenarios - Anforderungen - Profile - Ausbildung (s. 125-133). Wien: Verband Österreichischer Volkshochschulen.

Helmke, A. (2003). Unterrichtsqualität erfassen, bewerten, verbessen. Seelze: Kallmeyersche Verlagsbuchhandlung $\mathrm{GmbH}$.

Helmke, A. \& Schrader, F. W. (2006). Was ist guter Unterricht? Lehrerprofessionalität und Unterrichtsqualität. Den eigenen Unterricht reflektieren und beurteilen. Schulmagazin, 510(9), 5-12.

Helmke, A., et al. (2007). Der Ratingbogen der DESI-Videostudie. Dostupné z http://www .unilandau.de/helmke/download/index_buch.php

Helmke, A. (2009). Unterrichtsqualität und Lehrerprofessionalisierung. Diagnose, Evaluation und Verbesserung des Unterrichts. Seelze: Klett Verlag.

Hugener, I. (2006) Überblick über die Beobachtungsinstrumente. In K. Rakoczy, \& Ch. Pauli et al., Dokumentation der Erhebungs- und Auswertungsinstrumente zur schweizerischdeutschen Videostudie „Unterrichtsqualität, Lernverhalten und mathematisches Verständnis“ (s. 45-54). Frankfurt am Main: GFPF/DIPF.

Chvál, M. \& Starý, K. (2009). Kvalita a efektivita výuky: metodologické přístupy. In M. Janíková, \& K. Vlčková et al. Výzkum výuky: tematické oblasti, výzkumné přistupy a metody (s. 64-74). Brno: Paido.

Janík, T. et al. (2013). Kvalita (ve) vzdělávání. Brno: Masarykova univerzita.

Janík, T. (2012). Kvalita výuky: vymezení pojmu a způsobu jeho uživání. Pedagogika, 65(3), 244-261.

Janík, T., Lokajíčková, V., \& Janko, T. (2012). Komponenty a charakteristiky zakládající kvalitu výuky: přehled výzkumných zjištění. Orbis scholae, 6(3).

Klieme, E. et al. (2008). Unterricht und Kompetenzerwerb in Deutsch und Englisch. Ergebnisse der DESI-Studie. Weinheim - Basel: Beltz Verlag.

Meyer, H. (2004). Was ist guter Unterricht? Berlin: Cornelsen Verlag Scriptor GmbH.

Najvar, P., Najvarová, V., Janík, T., \& Šebestová, S. (2011). Videostudie v pedagogickém výzkumu. Brno: Paido.

Posch, P., \& Altrichter, H. (1997). Möglichkeiten und Grenzen der Qualitätsevaluation und Qualitätsentwicklung im Schulwesen. Innsbruck: Studien Verlag.

Seidel, T. (2003). Überblick über Beobachtungs- und Kodierungsverfahren. In T. Seidel, M. Prenzel, R. Duit, \& M. Lehrke. Technischer Bericht zur Videostudie „Lehr-Lern-Prozesse im Physikunterricht“ (s. 99-113). Kiel: IPN.

Seidel, T., Schulmeiß, I., \& Meyer, L. (2003). Vermischung von Lern- und Leistungssituationen. In T. Seidel, M. Prenzel, R. Duit, \& M. Lehrke, Technischer Bericht zur Videostudie „LehrLern-Prozesse im Physikunterricht“ (s. 229-238). Kiel: IPN.

Slavík, J. \& Lukavský, J. (2012). Hodnocení kvality expresivních tvořivých úloh ve výuce (na príkladu výtvarné výchovy). Orbis scholae, 6(3).

Trepke, C., Seidel, T., \& Dalehefte, I. M. (2003). Zielorientierung im Physikunterricht. In T. Seidel, M. Prenzel, R. Duit, \& M. Lehrke, Technischer Bericht zur Videostudie „Lehr-LernProzesse im Physikunterricht“ (s. 201-228). Kiel: IPN.

Šebestová, S. (2011). Př́ležitosti k rozvíjení řečových dovedností ve výuce anglického jazyka: videostudie. Brno: Masarykova univerzita.

Žák, V. (2006). Zjišt’ování parametrů kvality výuky fyziky (Disertační práce). Praha: MFF UK.

Zlatníček, P. (2011a). Kvalita výuky cizích jazyků - od vymezení pojmů k výzkumnému nástroji. In T. Janík, P. Najvar, \& M. Kubiatko et al., Kvalita kurikula a výuky: výzkumné př́stupy a nástroje (s. 115-130). Brno: Paido. 
76 Zlatníček, P. (2011b). Qualität des Fremdsprachenunterrichts - Präsentation des neuen Beobachtungsinstruments. Brünner Hefte zu Deutsch als Fremdsprache, (1/2), 105-113.

Zlatníček, P. (2011c). Kvalita ve výuce cizího jazyka - vývoj a pilotáž pozorovacího nástroje. In T. Janík, P. Knecht, \& S. Šebestová (Eds.), Smíšený design pedagogického výzkumu: sborník př́spěvků z 19. výročí konference České asociace pedagogického výzkumu. Brno: Masarykova univerzita.

Zlatníček, P. (2011d) Kvalita vyučování cizího jazyka: vznik a vývoj pozorovacího nástroje. In V. Janíková, M. Píšová, \& S. Hanušová et al., Metodologické otázky výzkumu výuky cizích jazyků (s. 141-149). Brno: Masarykova univerzita.

Zlatníček, P., Ducháčková, G., Knecht, P., Najvar, P., \& Janík, T. (2010a). Kvalita ve vzdělávání: vymezení a systematizace pojmů. In T. Janík, P. Knecht, \& P. Najvar et al. Nástroje pro monitoring a evaluaci kvality výuky a kurikula (s. 13-32). Brno: Paido.

Zlatníček, P., Ducháčková, G., \& Janík, T. (2010b). Kvalita výuky v oborech školního vzdělávání. In T. Janík, P. Knecht, \& P. Najvar et al., Nástroje pro monitoring a evaluaci kvality výuky a kurikula (s. 33-42). Brno: Paido.

Zlatníček, P. (2010c). Kvalita výuky cizího jazyka. In V. Janíková, M. Píšová, \& S. Hanušová et al., Cizí jazyky ve výzkumu (s. 111-124). Brno: Masarykova univerzita.

Pavel Zlatníček, Katedra německého jazyka a literatury, Pedagogická fakulta Masarykovy univerzity goldschmidchen@seznam.cz

Karolína Pešková, Institut výzkumu školního vzdělávání, Pedagogická fakulta Masarykovy univerzity peskova@ped.muni.cz 